\author{
А. А. Сазонов ${ }^{1,2}$ \\ ${ }^{1}$ Белорусский государственный технологический университет \\ ${ }^{2}$ РУП «Белгослес»
}

\title{
13-ЛЕТНЯЯ ДИНАМИКА СОСТОЯНИЯ ДУБРАВЫ В ПОЙМЕ РЕКИ БЕРЕЗИНЫ
}

На основании 13-летнего мониторинга на постоянной пробной площади описываются патологические и лесообразовательные процессы, происходящие в пойменной дубраве. Наблюдения характеризуют состояние дубового биогеоценоза на этапе восстановления после депрессии 2003-2008 гг. В послестрессовый период доминируют возбудители стволовых гнилей, поражающие деревья в сильной степени, и поперечный рак дуба, поражающий дубовый древостой в средней степени. Острых патологических процессов в насаждении не выявлено. Показано, что болезни и вредители леса в период депрессии выступают катализаторами сукцессионных изменений. Восстановление экосистемы пойменного леса происходит за счет формирования второго яруса древостоя из подроста, образующегося как под пологом леса, так и на прогалинах, оставшихся вследствие усыхания и вырубки дубов. При наличии семенного возобновления дуб не присутствует в составе второго яруса. Делается предположение, что сукцессионные процессы, происходящие на пробной площади, характерны для суходольных дубрав. В условиях нарастающей сухости климата здесь может сформироваться сложное насаждение с доминированием теневыносливых лиственных пород и единичными старыми дубами, возвышающимися над пологом леса.

Ключевые слова: Quercus robur L., пойменная дубрава, массовое усыхание, стволовые гнили, постоянная пробная площадь, лесопатологический мониторинг.

Для цитирования: Сазонов А. А. 13-летняя динамика состояния дубравы в пойме реки Березины // Труды БГТУ. Сер. 1, Лесное хоз-во, природопользование и перераб. возобновляемых ресурсов. 2021. № 2 (246). С. $128-137$.

\section{A. A. Sazonov ${ }^{1,2}$ \\ ${ }^{1}$ Belarusian State Technological University \\ ${ }^{2}$ RUE "Belgosles" \\ 13-YEAR-OLD DYNAMICS OF THE STATE OF FLOODPLAIN OAK FORESTS OF THE BEREZINA RIVER}

On the basis of 13-year monitoring on a permanent sample area, the pathological and forest-forming processes occurring in the floodplain oak forest are described. Observations characterise the state of the oak ecosystem at the stage of recovery after drying in 2003-2008. In the post-stress period, such chronic diseases dominate as invaders of stem rot, which attack trees to a great extend, and oak cancer, which affects the oak stand to an average degree. Acute pathological processes in the plantings are not revealed. It is shown that diseases and pests of the forest during the period of mass drying act as catalysts for successional changes in the stand. The restoration of the ecosystems of floodplain forests occurs due to the formation of the second tier of the stand of undergrowth, forming both under forest canopy and in the glades that appeared as a result of drying out and cutting down of oaks trees. If there is a natural renewal of oak, it is not present in the second tier. It is assumed that the succession processes occurring on the test area are characteristic for dry oak forests, since they have not been regulated by floods for several decades. In the conditions increasing dryness of the climate, a complex plantation may be formed here with the dominance of shade-tolerant broadleaved species of trees, and individual old oaks rising above the forest canopy.

Key words: Quercus robur L., floodplain oak forest, mass drying, stem rot, permanent sample area, forest pathology monitoring.

For citation: Sazonov A. A. 13-year-old dynamics of the state of floodplain oak forests of the Berezina river. Proceedings of BSTU, issue 1, Forestry. Nature Management. Processing of Renewable Resources, 2021, no. 2 (246), pp. 128-137 (In Russian).

Введение. Дубравы Беларуси, как и всей Восточной Европы, формируются в условиях периодических массовых усыханий, или «депрессий», как их назвал К. Б. Лосицкий [1]. Последнее подобное событие происходило в 20032008 гг. Эта депрессия была, вероятно, самой мощной для Беларуси из всех зафиксированных в литературе случаев массового усыхания и по прогнозным оценкам вызвала сокращение площади дубрав республики на 3,0 тыс. га и запаса дуба в составе твердолиственных насаждений на 1,5 млн м ${ }^{3}[2,3]$.

Особой частью лесного фонда республики являются пойменные дубравы, которые фактически 
представляют собой отдельную интразональную формацию $[4,5]$. Именно они в большей степени подвержены патологическим процессам, что делает задачу их сохранения особенно сложной $[6,7]$.

Известно, что в исторический период исчезло более 90\% всех пойменных лесов Европы, а оставшиеся сохранились в Центральной и Восточной Европе и часто имеют критическое состояние, страдая от засух и антропогенной нагрузки [8, 9]. В пойменных условиях, кроме обычных факторов, воздействующих на состояние лесных экосистем, добавляются особый гидрологический режим поймы, его антропогенная регуляция, повышенная активность вредных организмов, а также особые условия ведения лесного хозяйства, часто ограничивающие возможности лесоводов по проведению необходимых лесохозяйственных и лесозащитных мероприятий $[10,11]$. По сообщениям многих авторов [1215], пойменные леса нуждаются в особом режиме ведения лесного хозяйства. Пока остается не до конца выясненным вопрос, как происходит их восстановление после депрессии 2003-2008 гг. Требует уточнения роль патологических факторов в динамике состояния пойменных дубрав Беларуси. Сукцессионные процессы в дубравах речных долин могут быть весьма разнообразны, поэтому представляет интерес прогноз их дальнейшего состояния $[8,10,16]$. Поиску ответов на эти вопросы могут помочь данные, получаемые в ходе лесопатологического мониторинга на стационарных лесоводственных объектах, расположенных в пойменных дубравах.

Основная часть. Для оценки динамики состояния пойменных дубрав, изучения влияния патологических и лесообразовательных процессов на состав и структуру дубовых насаждений специалистами РУП «Белгослес» в Искровском лесничестве Светлогорского лесхоза (Гомельская область) в кв. 54 выд. 25 (лесоустройство 2011 г.) в насаждении с нарушенной устойчивостью и куртинно-групповым усыханием главной породы 25.06.2006 г. заложена постоянная пробная площадь (рис. 1, 2).

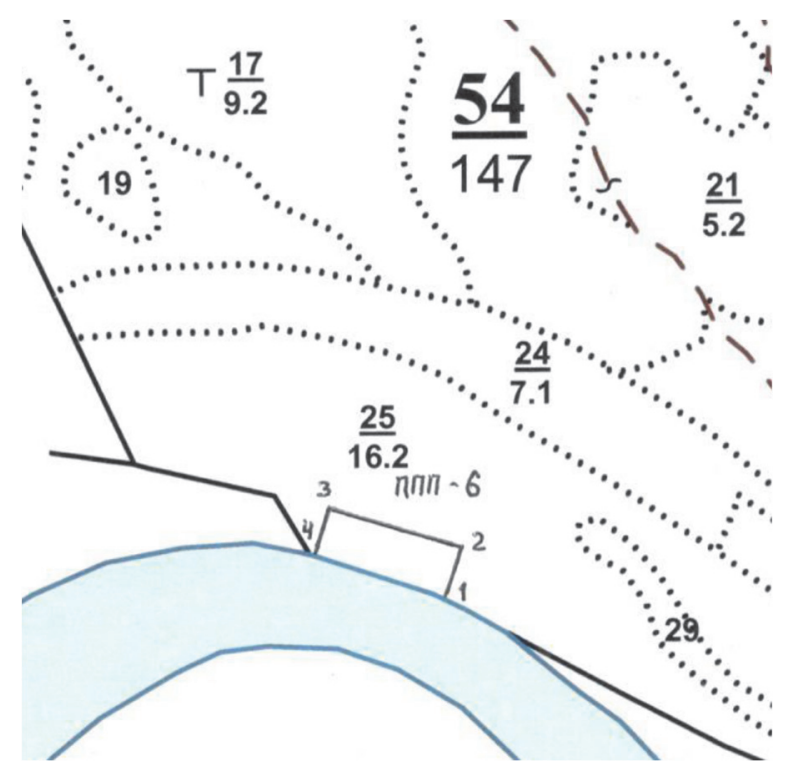

Рис. 1. Месторасположение пробной площади на планшете

По состоянию на 2019 г. она имеет следующие географические координаты (нумерация углов соответствует рис. 2): 1 - N 52 41.151', Е 29 40.909';

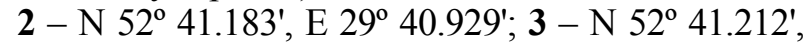
E $29^{\circ} 40.805^{\prime} ; 4-\mathrm{N} 52^{\circ} 41.181^{\prime}$, E $29^{\circ} 40.788^{\prime}$.

3

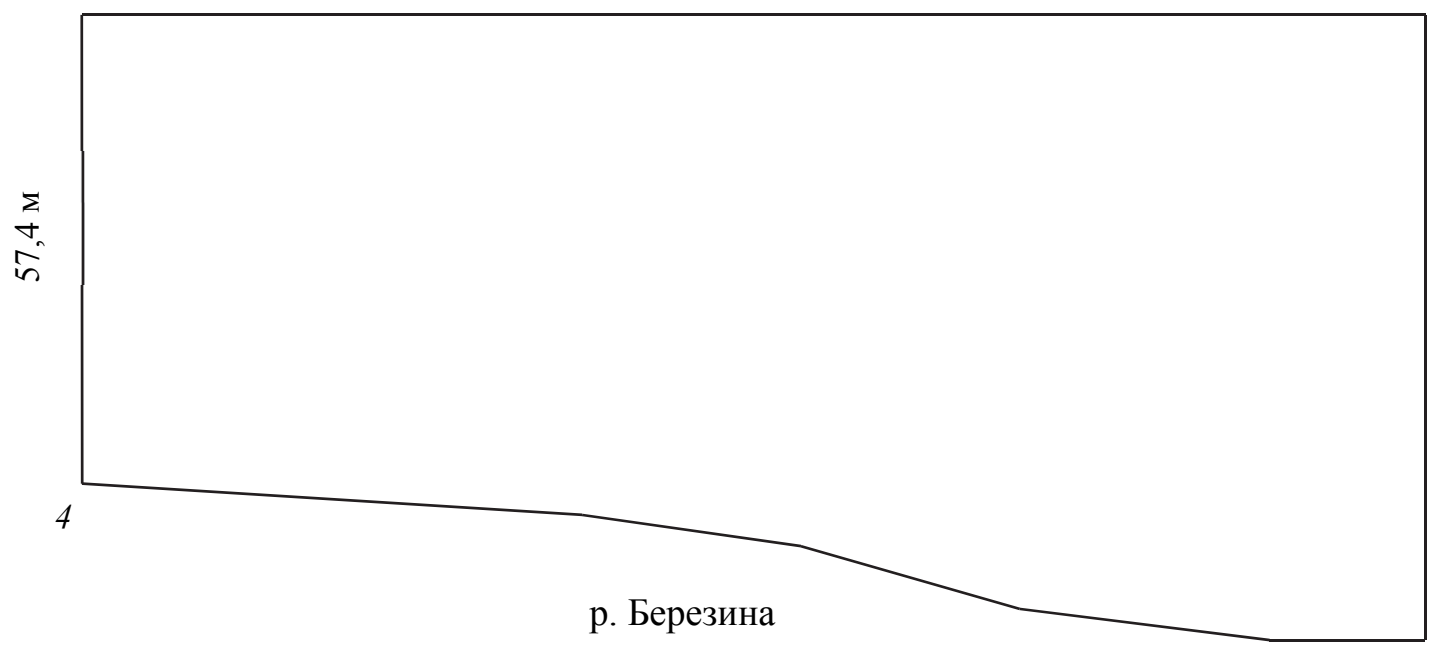

Рис. 2. Схема постоянной пробной площади по состоянию на 2019 г. 


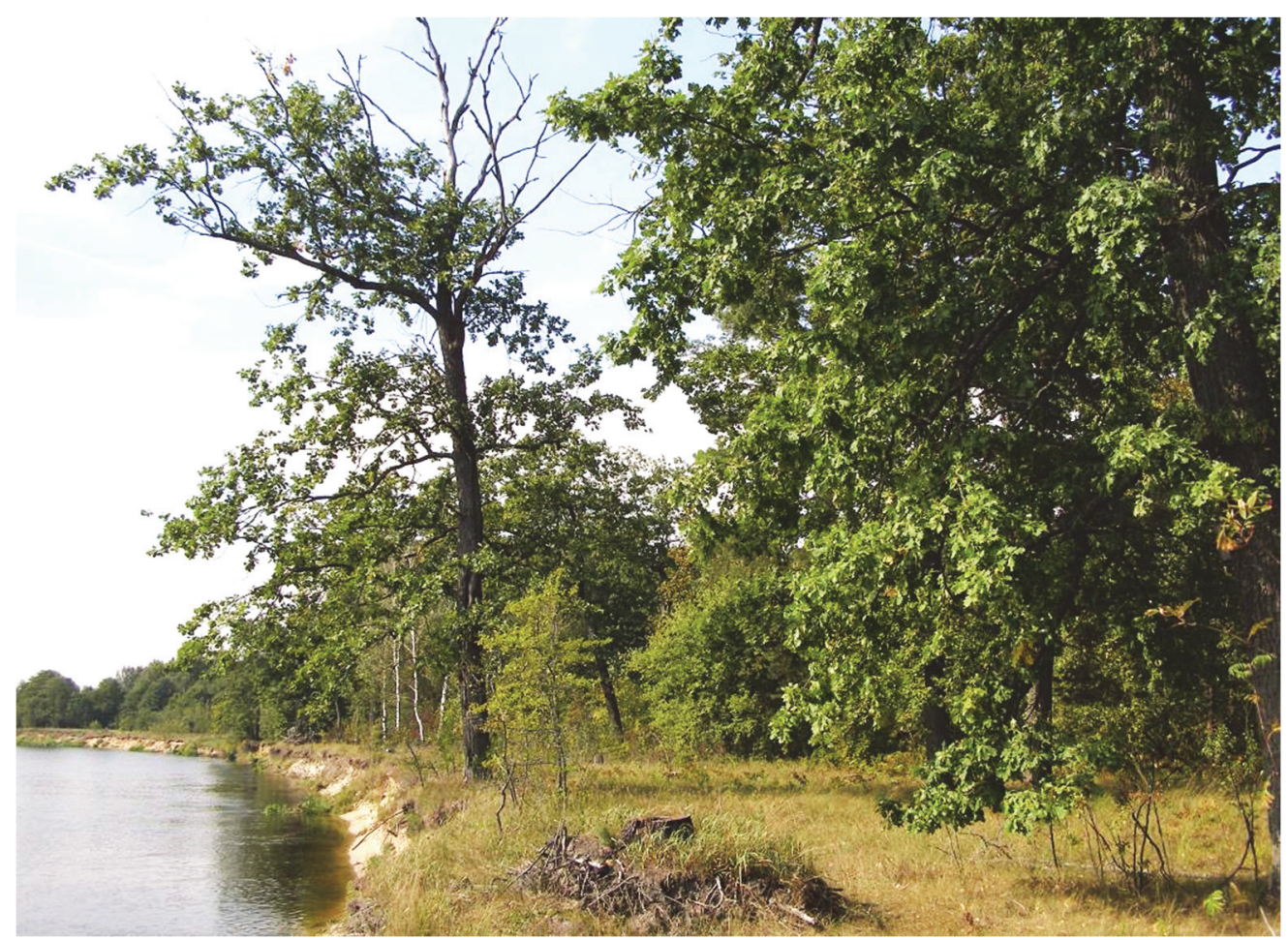

Рис. 3. Общий вид насаждения на пробной площади из точки 1 (19.09.2019)

Характеристика насаждения на момент закладки: дубрава естественного происхождения, состав - 10Д, возраст 137 лет, тип леса - дубрава прируслово-пойменная, IV бонитета (по таксационному описанию - злаково-пойменная, что не соответствует местоположению и бонитету). Местоположение: прирусловая пойма, на берегу р. Березины, рельеф ровный с западинами. В подросте клен, дуб, осина располагаются неравномерно. Подлесок редкий, представлен крушиной, рябиной, бузиной. В составе напочвенного покрова осоки, злаки. К моменту закладки пробной площади в насаждении уже накопилось существенное количество мертвой древесины -

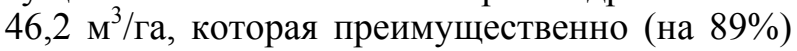
была представлена старым сухостоем. Объем валежа составлял всего 1,2 м³/га. Активная фаза усыхания к 2006 г. уже завершилась, поскольку размер текущего отпада составлял всего $4,0 \mathrm{~m}^{3} /$ га. Средневзвешенная категория состояния по запасу составила 3,3 , а по числу стволов 3,5 , что соответствует «сильно ослабленному» древостою [17]. В 2008, 2014 и 2019 гг. на пробной площади выполнялись повторные перечеты, их результаты представлены в таблице.

Динамика лесоводственных показателей. В 2012 г. на выделе, в том числе и на пробной площади, была проведена выборочная санитарная рубка. Количество деревьев главной породы на пробе снизилось с 99 (2006 г.) до 39 шт. (2019 г.) за счет вырубки и других причин. Кроме того, изза русловых процессов р. Березина подмывает берег в месте закладки пробной площади и часть деревьев теряет опору из-за осыпания и уноса грунта рекой (рис. 3), поэтому площадь пробы постепенно сокращается, а некоторые деревья падают в реку. В течение 2006-2019 гг. из-за рубки, усыхания, русловых процессов и естественного роста и развития древостоя поменялся состав первого яруса с $10 Д+\mathrm{C}$, Ос, Б до 8Д1С1Oc + Б, Кл.

Относительная полнота снизилась с 0,38 до 0,30. Запас первого яруса повышался до 2008 г., достигнув $112 \mathrm{~m}^{3} /$ га, а затем стал снижаться. Санитарное состояние древостоя улучшилось за счет проведения выборочной санитарной рубки в 2012 г., что подтверждается изменением средневзвешенной категории состояния дуба по количеству стволов с 3,5 (сильно ослабленное, 2008 г.) на 2,3 (ослабленное, 2019 г.), и по запасу с 3,3 на 2,1 (аналогично). В процессе выборочной санитарной рубки был вырублен сухостой, частично удалены захламленность и сильно ослабленные деревья, в результате количество мертвой древесины сократилось с 54,7 м³/га в 2008 г. до $3,1 \mathrm{~m}^{3} /$ га в 2014 г. В процессе рубки могло быть заготовлено до $51,6 \mathrm{~m}^{3} /$ га дубовой древесины, т. е. около $1 / 3$ исходного объема древесины на этом участке.

В 2019 г. для дуба был рассчитан индекс жизненного состояния (ИЖС), который составил $61,2 \%$, и показатель поврежденности древостоя (ППД) - 38,8\% [17]. По данным показателям можно охарактеризовать состояние дубового древостоя: ИЖС - ослабленное; ППД - поврежденное. 
Динамика лесоводственной и лесопатологической характеристик насаждения

\begin{tabular}{|c|c|c|c|c|c|}
\hline Параметры & Ед. & \multicolumn{4}{|c|}{ Значения } \\
\hline Год исследования & & 2006 & 2008 & 2014 & 2019 \\
\hline Площадь пробной площади & га & 0,98 & 0,98 & 0,94 & 0,89 \\
\hline Кол-во деревьев дуба 1-го яруса & шт./пп. & 99 & 95 & 44 & 39 \\
\hline В т. ч. жизнеспособных 1-го яруса & шт./пП. & 64 & 59 & 44 & 37 \\
\hline \multicolumn{6}{|c|}{ 1-й ярус } \\
\hline Состав & ед. & $10 Д+C$, Oc, Б & 9Д1Ос + С, Б, Кл & $8 Д 1 \mathrm{C} 1 \mathrm{Oc}+\mathrm{Б}$, Кл & 8Д1С1Ос + Б, Кл \\
\hline Возраст & лет & 137 & 139 & 145 & 150 \\
\hline Высота & $\mathrm{M}$ & 20,0 & 20,9 & 21,8 & 22,4 \\
\hline Диаметр & $\mathrm{cm}$ & 44,0 & 44,2 & 46,6 & 52,2 \\
\hline Бонитет & - & IV & IV & IV & IV \\
\hline Тип леса & - & Д. пр.-пм. & Д. пр.-пм. & Д. пр.-пм. & Д. пр.-пм. \\
\hline Абсолютная полнота & $\mathrm{M}^{2} / г \mathrm{a}$ & 11,8 & 10,9 & 10,0 & 10,4 \\
\hline Относительная полнота & - & 0,38 & 0,32 & 0,29 & 0,30 \\
\hline Запас живых деревьев & $\mathrm{m}^{3} / г \mathrm{a}$ & 106 & 112 & 110 & 101 \\
\hline Количество живых деревьев & шт./пп. & 82 & 77 & 66 & 50 \\
\hline \multicolumn{6}{|c|}{ 2-й ярус } \\
\hline Состав & ед. & 3ДЗОс3Лп1Б & 3КлЗЛп2Ос2Б & 4Кл4Лп2Б & 3КлЗЛп2Ос1Б1С \\
\hline Возраст & лет & 40 & 40 & 45 & 50 \\
\hline Высота & $\mathrm{M}$ & 12,0 & 12,5 & 13,5 & 15,1 \\
\hline Диаметр & $\mathrm{cm}$ & 20,0 & 14,1 & 15,7 & 14,3 \\
\hline Абсолютная полнота & $\mathrm{M}^{2} / г \mathrm{a}$ & 0,9 & 1,3 & 1,8 & 3,7 \\
\hline Относительная полнота & - & 0,04 & 0,05 & 0,06 & 0,12 \\
\hline Запас живых деревьев & $\mathrm{M}^{3} / г \mathrm{a}$ & 5 & 9 & 12 & 20 \\
\hline Количество живых деревьев & шт./пп. & 41 & 81 & 86 & 150 \\
\hline \multicolumn{6}{|c|}{ Подрост } \\
\hline Состав & ед. & & & 7Д1Кл1Ос1Олч & ЗДЗБр1Я1Кл1Ос1С \\
\hline Количество & шт./га & & & 2700 & 3800 \\
\hline \multicolumn{6}{|c|}{ Лесопатологическая характеристика } \\
\hline Класс биологической устойчиво & ости & II & II & II & II \\
\hline $\begin{array}{l}\text { Средневзвешенная категория с } \\
\text { по числу стволов }\end{array}$ & состояния & 3,5 & 3,6 & 2,0 & 2,3 \\
\hline $\begin{array}{l}\text { Средневзвешенная категория с } \\
\text { по запасу }\end{array}$ & состояния & 3,3 & 3,4 & 2,0 & 2,1 \\
\hline Текущий отпад & $\mathbf{m}^{3} / г \mathrm{a}$ & 4,0 & 2,8 & 0 & 4,1 \\
\hline Старый сухостой & $\mathrm{M}^{3} /$ га & 41,0 & 48,7 & 1,4 & 3,7 \\
\hline Ликвидная захламленность & $\mathrm{m}^{3} / г \mathrm{a}$ & 1,2 & 3,2 & 1,7 & - \\
\hline Общий объем мертвой древесины & $\mathbf{m}^{3} / г \mathrm{a}$ & 46,2 & 54,7 & 3,1 & 7,8 \\
\hline \multicolumn{6}{|c|}{ Болезни и повреждения } \\
\hline Стволовая гниль & $\%$ & 33,3 & 45,0 & 32,4 & 39,0 \\
\hline Ложный дубовый трутовик & $\%$ & 15,6 & 26,6 & 6,3 & 19,6 \\
\hline Инфекционное усыхание ветвей & $\%$ & 23,8 & 25,6 & 40,9 & 14,6 \\
\hline Поперечный рак & $\%$ & 11,0 & 13,6 & 23,9 & 17,0 \\
\hline Морозные трещины & $\%$ & 3,1 & 3,4 & 6,5 & - \\
\hline Механические повреждения & $\%$ & 3,1 & 3,4 & 2,2 & - \\
\hline Армиллариозная гниль & $\%$ & 34,3 & 7,6 & - & 2,3 \\
\hline Бактериальная водянка & $\%$ & 2,7 & 15,3 & - & 7,4 \\
\hline Заселено ксилофагами & $\%$ & 4,6 & 5,2 & - & 10,2 \\
\hline Отработано ксилофагами & $\%$ & 33,0 & 36,5 & - & 7,7 \\
\hline Объедание листогрызущими & $\%$ & - & - & 10 & - \\
\hline
\end{tabular}


Мы попытались проследить судьбу каждого дерева дуба 1-го яруса по данным перечетов на пробной площади за анализируемый период. Общее количество дубов за это время сократилось на 60 шт. (рис. 4, 5).

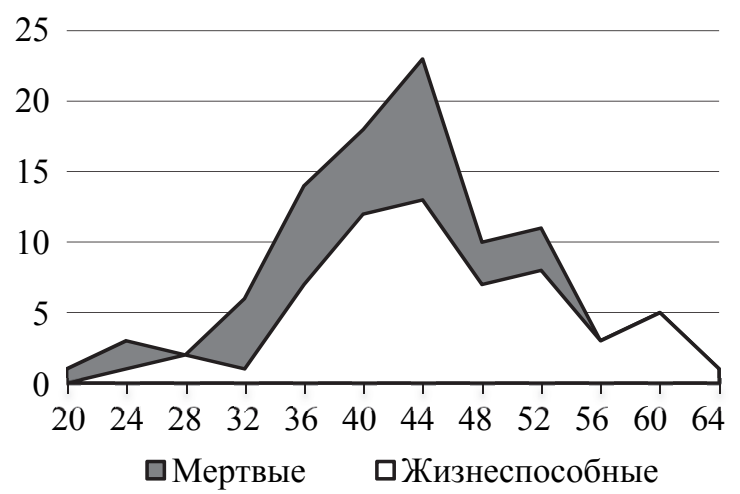

Рис. 4. Размерная структура дубового древостоя по состоянию на 2008 г. (количество деревьев, шт.)

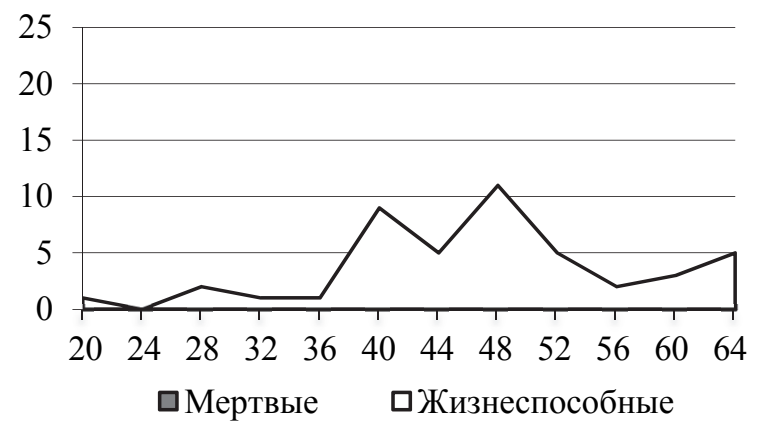

Рис. 5. Размерная структура дубового древостоя по состоянию на 2014 г. (количество деревьев, шт.)

Главной причиной убыли деревьев была выборочная санитарная рубка, в процессе которой удалили 49 дубов. В их число попали все сухостойные деревья (34 шт.), буреломные и валежные (3 шт.), а также часть сильно ослабленных деревьев (12 шт.). И хотя за время с 2008 (последний перечет перед рубкой) по 2012 г. часть из них могла перейти в категорию сухостоя, скорее всего в процессе рубки удалялись и некоторые жизнеспособные деревья из числа «сильно ослабленных». Это оказало влияние на параметры пораженности древостоя стволовыми гнилями и армиллариозной гнилью. Кроме этого, 7 деревьев унесла река, после рубки было повреждено ветром еще 3 дерева, а одно отставшее в росте перешло во 2-й ярус. В результате количество жизнеспособных дубов 1-го яруса сократилось за 13 лет с 64 до 37 шт. Далее подробнее охарактеризуем основные патологии дуба на пробной площади и их динамику.

Стволовые гнили. Насаждение на пробной площади является очагом стволовых гнилей и поражено дереворазрушающими грибами-биотрофами в сильной степени. За 2006-2008 гг. доля пораженных деревьев выросла с 48,9 до $71,6 \%$. Такой рост за короткий срок может объясняться лучшим выявлением признаков гнили при повторном перечете. Проведение выборочной санитарной рубки позволило снизить пораженность гнилями с 71,6 до 38,9\% в 2014 г., но за последующие 5 лет доля пораженных дубов возросла до 58,6\%. Таким образом, возбудители стволовых гнилей проявляют себя как типичные патогены, формирующие хронические очаги длительного действия в спелых и перестойных пойменных дубравах, в которых доля пораженных гнилями деревьев может колебаться в довольно широких пределах. При этом процесс гнилевого поражения в пойменной дубраве достаточно динамичен. Выборочные санитарные рубки могут частично снизить степень поражения древостоя гнилями за счет удаления некоторых пораженных деревьев, но из-за существующего запрета на вырубку усыхающих и сильно ослабленных деревьев в пойменных дубравах оздоровительный эффект рубок невелик [18]. Кроме того, доля пораженных деревьев слишком большая, поэтому их вырубка привела бы к окончательному разрушению дубового древостоя. Специализированным возбудителем стволовых гнилей в насаждении является ложный дубовый трутовик - Phellinus robustus (Karst.) Bourd. et Galz., поражение которым по внешним признакам отмечено в 2006 г. у 6,3\% деревьев, и резко возросло к 2019 г. - до 19,6\%. Доля ложного дубового трутовика в общем объеме гнилевого поражения, если принимать этот объем за $100 \%$, составляет от $16,2 \%$ в 2014 до $37,1 \%$ в 2008 г. Фактическое поражение данным патогеном может быть выше, но по данным некоторых авторов [19, 20], болезнь редко протекает скрыто и легко обнаруживается на растущих деревьях. Поэтому, хотя и не всегда, на пораженных деревьях формируются плодовые тела и характерные язвы, по которым можно определить видовую принадлежность возбудителя заболевания. В целом можно полагать, что визуальная оценка при перечете дает достаточно точную характеристику пораженности древостоя ложным дубовым трутовиком.

Усыхание ветвей. Инфекционное усыхание ветвей, вызываемое различными повреждениями проводящих тканей, выявлено изначально (2006 г.) у 23,8\% деревьев. Через два года оно отмечено у $25,6 \%$ дубов (средняя степень поражения). После проведения рубки в 2014 г. перечет показал наличие этой патологии у $40,9 \%$ дубов. Но в 2019 г. уровень поражения составил уже $14,6 \%$. По литературным данным известно, что в условиях Воронежской области (южная лесостепь) после дефолиации и частичного усыхания кроны восстановление ветвей у дуба занимает 
не менее 6 лет [21]. Возможно, восстановление крон после депрессии начала XXI в. на пробной площади к 2014 г. еще не завершилось. А в 2019 г. этот процесс зашел значительно дальше. Если принять гипотезу о более длительном процессе восстановления крон в спелых пойменных дубравах, тогда это может объяснить более высокий уровень проявления усыхания ветвей в 2014 г. Для уточнения этого предположения необходимы дальнейшие наблюдения за состоянием древостоя.

Поперечный рак. Доля деревьев, пораженных поперечным раком, среди дубов возрастала с 2006 по 2014 г. от 11,0 до 23,9\%. Достигнув максимума в 2014 г., далее пораженность этим заболеванием снизилась в 2019 г. до 17,0\%. Это может быть вызвано гибелью части пораженных деревьев в результате русловых процессов, а также зарастанием раковых ран и исчезновением внешних признаков этого заболевания со временем. Тем не менее степень поражения дубравы данным заболеванием не выходит в своих колебаниях за пределы «средней».

Морозные трещины и механические повреждения. Морозные трещины встречались на дубах в количестве от 3,1\% в 2006 до $6,5 \%$ в 2014 г. Затем к 2019 г. они исчезают из перечета. Механические повреждения ствола выявлены в небольшом количестве - от 3,1\% в 2006 до максимума в 2008 г. - 3,4\%. Далее в 2014 г. их доля сокращается до $2,2 \%$, что говорит о практическом отсутствии повреждения стволов во время проведения выборочной санитарной рубки в 2012 г. К 2019 г. деревья с признаками механических повреждений стволов исчезают из перечета. Таким образом, морозные трещины не оказывают заметного отрицательного влияния на состояние древостоя и зарастают со временем, исчезая из перечета в 2019 г. Механические повреждения могут как зарастать, так и трансформироваться в сухобочины, поврежденные стволовыми гнилями и усачами.

Корневые гнили. Армиллариозная гниль корней дуба развивалась на сухостойных и жизнеспособных дубах II-VI категорий санитарного состояния в 2006-2008 гг., в период депрессии дубовых насаждений. Доля пораженных деревьев в 2006 г. составляла 34,3\% от общего количества дубов. После вырубки сухостоя в 2012 г. поражение живых деревьев дуба корневыми гнилями на пробной площади не отмечается.

Бактериальная водянка. Поражение стволов бактериальными инфекциями, которое выявляется по выделению экссудата, засохшим черным пятнам в трещинах коры и мокрым участкам некрозов лубяной части коры, испытывает значительные колебания по годам. В 2006 г. поражение отмечалось всего у 2,6\% дубов, но через два года увеличилось до 15,3\%. В 2014 г. поражения бактериальной водянкой не выявлено, но в 2019 г. зафиксировано 7,4\% деревьев с признаками данного заболевания. Таким образом, этот патологический фактор часто присутствует в древостое, вызывая ослабление отдельных деревьев.

Стволовые вредители. Динамика повреждения древостоя стволовыми вредителями указывает на почти постоянное присутствие их на отдельных деревьях. Так, в 2006 г. доля повреждаемых ими деревьев составила 4,6\%, к 2008 г. она возросла до 5,2\%, а в 2014 г. после проведения выборочной санитарной рубки воздействия стволовых вредителей на древостой не зафиксировано. Но к 2019 г. в насаждении снова накопилось определенное количество ослабленных деревьев, главным образом от воздействия стволовых гнилей, и доля заселенных деревьев составила уже 10,2\%. Не все из них были заселены агрессивными видами ксилофагов. Из имеющихся трех заселенных деревьев два были заселены только усачами, обитающими на сухостое, а одно - двупятнистой узкотелой златкой (Agrilus biguttatus F.) и усачами. Повреждение златкой составило только $2,6 \%$ от числа дубов, поэтому насаждение на пробной площади не является очагом агрессивных стволовых вредителей дуба. Златки и усачи лишь используют ослабленные и усыхающие деревья как места переживания неблагоприятных для них условий в период восстановления дубрав. До проведения выборочной санитарной рубки на пробной площади имелось большое количество отработанных стволовыми вредителями деревьев - 33,0\% в 2006, и 36,5\% в 2008 г. Но после проведения рубки этих деревьев не осталось.

К 2019 г., через 7 лет после рубки, в насаждении появилось 7,7\% отработанных деревьев дуба, что свидетельствует о вялотекущих процессах ослабления древостоя различными биотическими факторами.

Листогрызущие вредители. Повреждения листвы филлофагами при проведении перечетов не выявлено, за исключением 2014 г., когда среднее повреждение листового полога насекомыми составило около $10 \%$.

Динамика 2-го яруса. Частичное усыхание дубового древостоя привело к освобождению территории от затенения и стимулировало интенсивное развитие 2-го яруса. За прошедшие 13 лет наблюдений состав 2-го яруса претерпел существенные изменения. Изначально в 2006 г. он имел состав 3ДЗОс3Лп1Б (40 лет), высотой 12 м и диаметром 20 см, насчитывая на пробной площади 41 дерево с объемом $5 \mathrm{~m}^{3} /$ га. Этот 2-й ярус был в значительной степени унаследован от предыдущего состояния древостоя, когда полнота 
1-го яруса была выше, и затенение препятствовало формированию подроста. Затем на пробной площади во 2-м ярусе стали доминировать теневыносливые виды, врастающие в этот ярус из подроста, и состав древостоя за два года изменился до ЗКлЗЛп2Ос2Б + Д, С (40 лет), высотой 12,5 м и диаметром 14,1 см, количество деревьев на пробной площади увеличилось до 81, а их запас до 9 м $3 /$ га. Проведение выборочной санитарной рубки не оказало заметного отрицательного влияния на состояние 2-го яруса, и к 2014 г. он имел состав 4Кл4Лп2Б + Д, С (45 лет), высотой 13,5 м и диаметром 15,7 см, с количеством деревьев 86 шт. на пробной площади и запасом $15 \mathrm{~m}^{3} /$ га. Дальнейшее развитие лесовосстановительных процессов привело к увеличению числа деревьев в составе 2-го яруса, росту его запаса и видового разнообразия. Так, к 2019 г. сформировался состав 3КлЗЛп2Ос1Б1С + Д, Я, Олч, Ивд (50 лет), высотой 15,1 м и диаметром 14,3 см, в количестве 150 деревьев на пробной площади и запасом $20 \mathrm{~m}^{3} /$ га.

Процесс пополнения 2-го яруса за счет подроста продолжается, поэтому, несмотря на прошедшие 13 лет, средний возраст 2-го яруса изменился в меньшей степени, чем прошло лет с момента первого перечета. То же относится к высоте и диаметру. Теневыносливые клен и липа сохраняют устойчивое господство, а встречающийся в подросте берест (Ulmus minor Mill.) не может выйти из подроста во 2-й ярус по причине поражения голландской болезнью, очаг которой действует в хроническом виде на протяжении всего периода наблюдений. Берест постепенно выпадает из состава подроста, так и не успев достигнуть необходимой высоты для вхождения во 2-й ярус, что стимулирует развитие клена остролистного и создает условия для его доминирования в будущем древостое.

Подрост. Из-за малочисленности подрост при первых двух перечетах не учитывался. Частичное усыхание деревьев 1-го яруса и их вырубка при проведении выборочной санитарной рубки посодействовали интенсивному развитию подроста за счет повышения интенсивности светового потока, достигающего поверхности почвы. В 2014 г. на пробной площади было учтено в переводе на условно средний подрост 7Д1Кл1Ос1Олч (2,7 тыс. шт./га). Через 5 лет количество подроста увеличилось. В 2019 г. учтено в переводе на условно средний 3ДЗБр1Я1Кл1Ос1С (3,8 тыс. шт./га). Площадки по учету подроста закладывались вдоль визиров с трех сторон (со стороны реки не закладывались), через равные расстояния, по пять площадок на каждой стороне, всего 15 площадок прямоугольной формы размером $4 \times 5$ м каждая. Общая площадь обследования подроста составила
$300 \mathrm{~m}^{2}$. Особенностью возобновления является то, что при наличии дуба в составе подроста (в мелком подросте дуб доминирует) он практически не выходит во 2-й ярус. Уже в составе крупного подроста дуб встречается очень редко. В то же время клен выживает и является наиболее перспективной древесной породой для данного участка. Липа возобновилась в насаждении ранее, еще до первого перечета, и сейчас поддерживает свое участие в составе 2-го яруса не путем семенного возобновления, а порослью от материнских деревьев, которые в результате формируют «кусты возобновления», быстро выходя во 2-й ярус и выдерживая, таким образом, конкуренцию с кленом за пространство. На прогалинах, которые образовались после усыхания и вырубки дубов и еще не успели зарасти, успешно возобновляются светолюбивые сосна, береза и осина.

Заключение. На пробной площади 1-й ярус уже достиг возраста спелого древостоя для пойменной дубравы (150 лет), и в дальнейшем логично ожидать продолжения его постепенного распада. За 2006-2019 гг. острых патологических процессов в дубраве не зафиксировано, но во время последней депрессии начала XXI в. около $1 / 3$ запаса дубового древостоя перешло в мертвый лес. Наблюдения показывают, что в дальнейшем можно ожидать прогрессирования хронических заболеваний и увеличения степени поражения дубового древостоя стволовыми гнилями. Периодически может повторяться объедание дубов листогрызущими насекомыми. Но после сильного изреживания древостоя в результате усыхания и рубки процесс накопления сухостойных деревьев проходит медленными темпами. Ожидается, что разрушение дубового древостоя может растянуться на десятилетия, если не будет осложнено новым циклом массового усыхания.

Кроме того, развитие русловых процессов будет приводить к постепенному размыву левого берега $\mathrm{p}$. Березины и поглощению части территории пробной площади рекой. Например, за 2006-2019 гг. уже произошло уменьшение площади с 0,98 до 0,89 га.

Гибель значительного количества деревьев дуба и их вырубка способствовали освобождению пространства под пологом леса, что стимулировало естественное возобновление. На пробной площади идет интенсивный процесс формирования нового поколения леса - 2-го яруса и подроста из широкого спектра древесных видов. В перспективе здесь может сформироваться сложное разновозрастное насаждение с единичными дубами, господствующими над основным пологом древостоя, и теневыносливыми кленом и липой в 1-м ярусе, с некоторой примесью 
мягколиственных пород. Участие дуба в новом поколении леса, вероятно, будет исключено по причине высокой конкуренции со стороны других древесных пород. Сукцессионные процессы, происходящие на пробной площади, характерны для суходольных дубрав, в которых в процессе развития происходит постепенное вытеснение дуба из древостоя его спутниками [4, 22, 23, 24]. Подобное явление последние годы стало наблюдаться и в некоторых лесах речных долин, например в пойменных дубравах Хорватии [9]. Причиной этому, по мнению ряда авторов, служит реакция лесных экосистем на повышение температуры, снижение количества осадков и уровня воды в реках в меженный период, а также сокращение частоты и интенсивности паводков [7, 9].
Аналогичную ситуацию мы наблюдаем и на пробной площади. Судя по составу подроста и 2-го яруса, сукцессионные процессы на повышенных элементах рельефа прирусловой поймы, на которой расположено исследуемое насаждение, уже, возможно, несколько десятков лет не регулируются половодьями. Поэтому там успешно возобновляются спутники дуба, вытесняя естественное возобновление главной породы. А болезни и вредители леса, ускоряя гибель дубов, особенно в период депрессии, выступают катализаторами сукцессионных процессов в дубовом древостое.

Автор выражает искреннюю признательность специиалистам РУП «Белгослес», участвовавиим в разное время в проведении работ на пробной площзади.

\section{Список литературы}

1. Лосицкий К. Б. Явления депрессии в твердолиственных лесах // Лесное хозяйство. 1975. № 12. C. $40-44$.

2. Сазонов А. А. Оценка последствий массового усыхания дубовых лесов Беларуси 2003-2008 гг. // Труды БГТУ. Сер. І: Лесное хозяйство. 2009. Вып. XVII. С. 304-307.

3. Федоров Н. И., Сазонов А. А. Оценка последствий массового усыхания дубрав Беларуси // Проблемы лесной фитопатологии и микологии: сб. материалов VII Междунар. конф., г. Пермь, 7-13 сент. 2009 г. Пермь: Перм. гос. пед. ун-т, 2009. С. 194-197.

4. Лосицкий К. Б. Восстановление дубрав. М.: Изд-во с-хоз. литературы, журналов и плакатов, 1963. $359 \mathrm{c}$.

5. Экосистемы Теллермановского леса / отв. ред. В. В. Осипов. М.: Наука, 2004. 340 с.

6. Потапенко А. М. Пойменные дубравы Национального парка «Припятский»: типологическая структура, состояние, динамика и прогноз // Лесная типология: современные методы выделения типов леса, классификация и районирование лесной растительности: материалы Междунар. науч. семинара, Минск - Нарочь, 20-21 окт. 2016 г. Минск: Колоград, 2016. С. 218-223.

7. Stojanović D. B., Levanič, T., Matović B. et al. Growth decrease and mortality of oak floodplain forests as a response to change of water regime and climate. Eur. J. Forest Res. 2015. Vol. 134. P. 555-567. DOI.org/10.1007/s10342-015-0871-5.

8. Затопляемый лес: Руководство по восстановлению пойменных лесов для лиц, определяющих политику и менеджеров рек в Европе / Edited by Francine Hughes. The FLOBAR2 Project, Cambridge: University of Cambridge, 2003. 90 p.

9. Mikac S., Žmegač A., Trlin D. И Drought-induced shift in tree response to climate in floodplain forests of Southeastern Europe. Scientific Reports. 2018. Vol. 8. Article number: 16495. DOI:10.1038/s41598-01834875-w.

10. Углянец А. В. Усыхание пойменных лесов Припяти: его причины и последствия // Лесное и охотничье хозяйство. 2006. № 3. С. 20-25.

11. Гримашевич В. В., Маховик И. В., Левенкова О. В. Пойменные дубравы Республики Беларусь и их состояние // Проблемы лесоведения и лесоводства: сб. науч. тр. Гомель: Институт леса НАН Беларуси, 2007. Вып. 67. С. 37-49.

12. Гельтман В. С., Моисеенко И. Ф. Пойменные леса Припяти и их трансформация в связи с мелиорацией. Минск: Навука і тэхніка, 1990. 118 с.

13. Ткач В. П. Пойменные дубравы Украины и совершенствование хозяйствования в их // Дуб порода третьего тысячелетия: сб. науч. тр. Гомель: Институт леса НАН Беларуси, 1998. Вып. 48. C. 361-366.

14. Калиниченко Н. П., Румянцева С. А. Пойменные дубравы // Дуб - порода третьего тысячелетия: сб. науч. тр. Гомель: Институт леса НАН Беларуси, 1998. Вып. 48. С. 366-369.

15. Гримашевич В. В. Проблемы воспроизводства пойменных дубрав Беларуси // Рациональное использование и воспроизводство лесных ресурсов в системе устойчивого развития: материалы Междунар. науч.-практ. конф. Гомель, 5-7 сент. 2007 г. Гомель: Институт леса НАН Беларуси, 2007. C. $155-159$. 
16. Водные ресурсы Национального парка «Припятский», их влияние на состояние лесных экосистем / А. В. УГлянец [и др.]; под общ. ред. Г. И. Марцинкевич. Минск: БГПУ, 2007. 163 с.

17. Защита леса / В. Б. Звягинцев [и др.]. Минск: БГТУ, 2019. 164 с.

18. Об утверждении Санитарных правил в лесах Республики Беларусь: постановление М-ва лесного хоз-ва Респ. Беларусь, 19 дек. 2016, № 79 // Нац. реестр правовых актов Респ. Беларусь. 2016. $8 / 31603$.

19. Вакин А. Т. Фитопатологическое состояние дубрав Теллермановского леса // Труды Института леса АН СССР. 1954. Т. XVI. С. 5-109.

20. Харченко Н. А., Харченко Н. Н. Санитарное состояние дубрав как показатель их деградации // Деградация дубрав Центрального Черноземья. Воронеж: ГОУ ВПО «ВГЛТА», 2010. С. 360-499.

21. Ильюшенко А. Ф., Романовский М. Г. Формирование вторичной кроны дуба и ее роль в динамике состояния древостоев // Лесоведение. 2000. № 3. С. 65-72.

22. Матвеев С. М., Мельников Е. Е. Сукцессионные процессы и их направленность в дубравах Центрального Черноземья // Деградация дубрав Центрального Черноземья. Воронеж: ГОУ ВПО «ВГЛТА», 2010. С. 500-602.

23. Чеботарёв П. А., Чеботарёва В. В., Стороженко В. Г. Структура и состояние древостоев в дубравах Теллермановского опытного лесничества // Лесоведение. 2016. № 5. С. 375-382.

24. Потапенко А. М., Гримашевич В. В. Естественное возобновление плакорных дубрав Беларуси: состояние и перспективы // Проблемы лесоведения и лесоводства: сб. науч. тр. Гомель: Институт леса НАН Беларуси, 2010. Вып. 70. С. 88-97.

\section{References}

1. Lositskiy K. B. Depression phenomena in hardwood forests. Lesnoye khozyaystvo [Forestry], 1975, no. 12, pp. 40-44 (In Russian).

2. Sazonov A. A. Assessment of the consequences of mass drying out of oak forests in Belarus in 20032008. Trudy BGTU [Proceedings of BSTU], series I, Forestry, 2009, issue XVII, pp. 304-307 (In Russian).

3. Fedorov N. I., Sazonov A. A. Assessment of the consequences of mass drying out of oak forests in Belarus. Sb. materialov. VII Mezhdunar. konf. "Problemy lesnoy fitopatologii i mikologii". [Collection of articles. mater. VII Int. conf. "Problems of forest phytopathology and mycology”]. Perm', 2009, pp. 194-197 (In Russian).

4. Lositskiy K. B. Vosstanovleniye dubrav [Restoration of oak forests]. Moscow, Izd-vo sel'khoz. literatury, zhurnalov i plakatov Publ., 1963. 359 p.

5. Ekosistemy Tellermanovskogo lesa [Ecosystems of the Tellerman forest] / ed. V. V. Osipov. Moscow, Nauka Publ., 2004. 340 p.

6. Potapenko A. M. Floodplain oak forests of the Pripyatsky National Park: typological structure, state, dynamics and forecast. Materialy. Mezhdunar. nauch. seminara "Lesnaya tipologiya: sovremennyye metody vydeleniya tipov lesa, klassifikatsiya i rayonirovaniye lesnoy rastitel'nosti" [Materials Int. scientific seminar "Forest typology: modern methods for identifying forest types, classification and regionalization of forest vegetation"]. Minsk, 2016, pp. 218-223 (In Russian).

7. Stojanović D. B., Levanič, T., Matović B. et al. Growth decrease and mortality of oak floodplain forests as a response to change of water regime and climate. Eur. J. Forest Res., 2015, vol. 134, pp. 555567. DOI.org/10.1007/s10342-015-0871-5.

8. The Flooded Forest: Guidance for policy makers and river managers in Europe on the restoration of floodplain forests. Edited by Francine Hughes. The FLOBAR2 Project, Cambridge, University of Cambridge, 2003. 90 p.

9. Mikac S., Žmegač A., Trlin D. et al. Drought-induced shift in tree response to climate in floodplain forests of Southeastern Europe. Scientific Reports, 2018, vol. 8, Article number: 16495. DOI:10.1038/s41598-018-34875-w.

10. Uglyanets A. V. Drying of the floodplain forests of Pripyat: its causes and consequences. Lesnoye $i$ okhotnich'ye khozyaystvo [Forestry and hunting], 2006, no. 3, pp. 20-25 (In Russian).

11. Grimashevich V. V., Makhovik I. V., Levenkova O. V. Floodplain oak forests of the Republic of Belarus and their condition. Sbornik nauchnykh trudov "Problemy lesovedeniya i lesovodstva" [Collection of scientific papers "Problems of forest science and forestry"], 2007, issue 67, pp. 37-49 (In Russian).

12. Gel'tman V. S., Moiseenko I. F. Poymennyye lesa Pripyati $i$ ikh transformatsiya $v$ svyazi $s$ melioratsiyey [Floodplain forests of Pripyat and their transformation due to land reclamation]. Minsk, Navuka i tekhnika Publ., 1990. 118 p.

13. Tkach V. P. Floodplain oak forests of Ukraine and improvement of management in their. Sbornik nauchnykh trudov "Problemy lesovedeniya i lesovodstva" [Collection of scientific papers "Problems of forest science and forestry"], 1998, issue 48, pp. 361-366 (In Russian). 
14. Kalinichenko N. P., Rumyantseva S. A. Floodplain oak forests. Sbornik nauchnykh trudov "Problemy lesovedeniya i lesovodstva" [Collection of scientific papers "Problems of forest science and forestry"], 1998, issue 48, pp. 366-369 (In Russian).

15. Grimashevich V. V. Reproduction problems of floodplain oak forests in Belarus. Materialy Mezhdunar. nauch.-prakt. konf. "Ratsional'noye ispol'zovaniye $i$ vosproizvodstvo lesnykh resursov $v$ sisteme ustoychivogo razvitiya" [Mater. Int. scientific-practical conf. "Rational use and reproduction of forest resources in the system of sustainable development"]. Gomel', 2007, pp. 155-159 (In Russian).

16. Uglyanets A. V., Vlasov B. P., Khmelevskiy V. I., Rudakovskiy I. A., Gigevich G. S., Arkhipenko T. V., Chekan G. S. Vodnyye resursy Natsional'nogo parka "Pripyatskiy", ikh vliyaniye na sostoyaniye lesnykh ekosistem [Water resources of the National park "Pripyatsky", their influence on a forest ecosystems condition]. Minsk, BGPU Publ., 2007. 163 p.

17. Zvyagintsev V. B., Blintsov A. I., Kozel A. V., Kukhta V. N., Sazonov A. A., Seredich M. O., Khvasko A. V. Zashchita lesa [Forest protection]. Minsk, BGTU Publ., 2019. 164 p.

18. On approval of Sanitary forest regulations in the Republic of Belarus: decree of the Ministry of Forestry of the Republic of Belarus, December 19, 2016, no. 79. Natsional'nyy reestr pravovykh aktov Respubliki Belarus' 'National Register of Legal Acts of the Republic of Belarus], 2016. 8/31584.

19. Vakin A. T. Phytopathological state of oak forests of Tellermanovsky forest. Trudy Instituta lesa AN SSSR [Proceedings of the Institute of Forestry of the USSR Academy of Sciences], 1954, issue XVI, pp. 5-109 (In Russian).

20. Kharchenko N. A., Kharchenko N. N. Sanitary condition of oak forests as an indicator of their degradation. Degradatsiya dubrav Tsentral'nogo Chernozem'ya [Degradation of oak forests of the Central Chernozem region]. Voronezh, GOU VPO "VGLTA" Publ., 2010, pp. 360-499 (In Russian).

21. Il'yushenko A. F., Romanovskiy M. G. Formation of the secondary oak crown and its role in the dynamics of the state of forest stands. Lesovedeniye [Forestry], 2000, no. 3, pp. 65-72 (In Russian).

22. Matveev S. M., Mel'nikov E. E. Successional processes and their direction in oak forests of the Central Chernozem region. Degradatsiya dubrav Tsentral'nogo Chernozem'ya [Degradation of oak forests of the Central Chernozem region]. Voronezh, GOU VPO "VGLTA" Publ., 2010, pp. 500-602 (In Russian).

23. Chebotarev P. A., Chebotareva V. V., Storozhenko V. G. The structure and condition of forest stands in the oak forests of the Tellermanovsky experimental forestry. Lesovedeniye [Forestry], 2016, no. 5, pp. 375-382 (In Russian).

24. Potapenko A.M., Grimashevich V.V. Natural renewal of dry oak forests in Belarus: state and prospects. Sbornik nauchnykh trudov "Problemy lesovedeniya i lesovodstva" [Collection of scientific papers "Problems of forest science and forestry"], 2010, issue 70, pp. 88-97 (In Russian).

\section{Информация об авторе}

Сазонов Александр Александрович - старший преподаватель кафедры лесозащиты и древесиноведения. Белорусский государственный технологический университет (220006, г. Минск, ул. Свердлова, 13а, Республика Беларусь). Начальник лесоустроительной партии 1-й Минской лесоустроительной экспедиции РУП «Белгослес» $(220089$, г. Минск, ул. Железнодорожная, 27, Республика Беларусь). E-mail: lesopatolog@rambler.ru

\section{Information about the author}

Sazonov Aleksandr Aleksandrovich - Senior Lecturer, the Department of Forest Protection and Wood Science. Belarusian State Technological University (13a, Sverdlova str., 220006, Minsk, Republic of Belarus). Head of 1 Minsk Forest Inventory Expedition. RUE "Belgosles" (27, Zheleznodorozhnaya str., 220089, Minsk, Republic of Belarus). E-mail: lesopatolog@rambler.ru 